\title{
A Newly Found Kansas Legal Broadside
}

\author{
M.H. Hoeflich ${ }^{*}$ \\ Allison C. Reeve
}

I. INTRODUCTION

In 2014 the Wheat Law Library at the University of Kansas School of Law acquired a legal broadside issued by the Fredonia, Kansas law firm of Miller \& Chase in the late nineteenth century. The broadside casts important new light not only on the practice of law in Kansas during its first decades, but also on legal printing in Kansas during that period.

\section{THE CONTEXT OF THE BROADSIDE}

Wilson County was first established in 1855 by the Territorial Legislature, out of what was then Osage land. ${ }^{1}$ In 1864, thirty residents of the county formally petitioned Governor Thomas Carney for formal recognition of the county. ${ }^{2}$ Fredonia was organized as a city of the third class in 1871. After a series of contested elections between 1869 and 1873, Fredonia was selected as the county seat of Wilson County, which meant, of course, that the county courthouse would be located there and that the city would become the legal center of the county thereafter. The courthouse was the second building erected in the city. ${ }^{3}$

\footnotetext{
${ }^{*}$ John H. and John M. Kane Distinguished Professor of Law, University of Kansas School of Law.

${ }^{\dagger}$ Cataloging \& Technical Services Librarian, University of Kansas School of Law Wheat Law Library. I would like to thank the efforts of student assistants, Kasey Considine, Sadie Shillieto, and Tamara Combs who helped in research for this article, curating the broadside for future generations of researchers, and editing this article for publication. I also extend my gratitude to Pamela Crawford who worked to secure access to various scarce resources. Lastly, I thank the Kansas Law Review Staff and Board who work tirelessly and diligently.1. Details on the history of Wilson County and its county seat, Fredonia, are drawn from WiLLIAM G. CUTLER, HisTORY OF THE STATE OF KANSAS II 900-12 (1883).

2. Id. at 901 .

3. Id.
} 
Adoniram J. Miller arrived in Kansas territory on November 14, 1854, and settled for eighteen months in Douglas County. ${ }^{4} \mathrm{He}$ then enlisted in the U.S. Army and fought in the Civil War. After his military service, he returned to Kansas and settled in Fredonia. He was elected as the clerk of the Fredonia School Board on July 10, 1869. In 1879, Miller appears to have entered into the practice of law in Fredonia in partnership with Christopher Columbus Chase (who appears to have also moved to Fredonia in 1869).

The practice of law in Kansas during the 1870s and 1880s was very much general practice. Lawyers tended to do much of their work in three courts-general trial courts, probate courts, and justices' courts. Office practice consisted primarily of contracts and commercial document drafting, and probate and testamentary work. ${ }^{6}$

During the nineteenth century, lawyers routinely advertised their services in newspapers and other periodicals. The most common form of advertising took the form of a printed "business card" format advertisement, usually found either on the first or on the last page of a

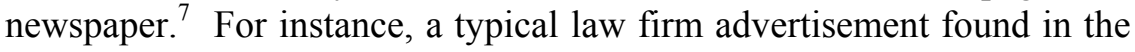
Kansas Daily Tribune in 1868 read:

\author{
SMITH \& HAMPTON \\ Attorneys at Law \\ War Claims Agents, \\ AND NOTARY PUBLIC, \\ LAWRENCE, KANSAS \\ WILL PRACTICE IN DIFFERENT Courts of this State. \\ Particular attention given to collecting and securing \\ Claims. Office over Geo. Leis Drug Store ${ }^{8}$
}

4. H.R. Misc. Doc. No. 35-43, vol. 2, at 559 (1859) (affidavit of A.J. Miller).

5. CUTLER, supra note 1, at 902 .

6. See Michael H. Hoeflich, Legal Fees in Nineteenth Century Kansas, 48 U. KAN. L. REV. 991 (2000) [hereinafter Legal Fees]; see also Paul E. WILsON, How the Law Came to Kansas, in MUSINGS OF SMILING BULL 77 (2000). For the nature of legal practice in another small Kansas town of the period, see Michael H. Hoeflich, The Lawyers of Old Lecompton, in TALLGRASS ESSAYS: PAPERS FROM THE SYMPOSIUM IN HONOR OF DR. RAMON POWERS 27 (Michael H. Hoeflich, Gayle R. Davis \& Jim Hoy eds., 2003).

7. See A Brief Early History of Lawyer Advertising in the United States, OMNILEARN, http://omnilearn.net/ethics/pdfs/lesson2historypodcast.pdf (last visited May 19, 2015); Legal Fees, supra note 7 , at 995 .

8. Advertisement, KAN. DAILY TRIB., May 1, 1868, at 1; Legal Fees, supra note 7, at 995. 
In addition to explicit advertisements by individual lawyers and law firms, local bar associations also published lists of minimum charges for various types of legal work done in particular jurisdictions. ${ }^{9}$ These fee lists were generally published as a single sheet broadside. ${ }^{10}$

\section{THE MiLler \& CHASE BROADSIDE}

\section{A. Physical Attributes}

The medium being a broadside, the piece consists only of a single sheet without binding. Although missing the bottom right corner due to unknown damage, the total dimension of the original broadside is $14 \times 31$ $\mathrm{cm}(51 / 2 \times 123 / 16 \mathrm{in})$. Indentation of a horizontal fold does exist almost precisely half way down the sheet (at $153 / 4 \mathrm{~cm}$ or $61 / 2 \mathrm{in}$ ), indicating original insertion in the Courier, or an individual's tucking it away for later review. In addition to the fold and torn corner, other water and aging marks are present, but the broadside is not in a state of deterioration.

The typeface of the printed matter differs widely within this single sheet. Centered at the top after the initials and surnames of the attorneys, the largest and most emboldened type is printed:

\section{MILLER \& CHASE ATTORNEYS AT LAW, Fredonia, Wilson County, Kansas, PRACTICE IN THE PROBATE COURT}

The typeface of the bulk of the text, below this heading, is much smaller, with italics used as emphasis in certain areas. The attorneys' names again appear larger and emboldened below. Nineteenth-century typeface is difficult to ascertain, ${ }^{11}$ however most of the fonts contain serifs and are similar to Times New Roman or Roman italics. Instances not appearing Roman are decorative. ${ }^{12}$ 7 , at 1002

9. See, e.g., the 1869 Douglas County Bar Tariff of Fees reproduced in Legal Fees, supra note

10. For the history of the printing and use of broadsides in the United States, see Ian Brabner, American Broadsides, History on a Sheet of Paper, THE New AntiQuarian Blog (July 16, 2014), www.abaa.org/blog/post/american-broadsides-history-on-a-sheet-of-paper.

11. Philip Gaskell, A NeW Introduction to Bibliography 210 (1972).

12. See generally Christopher Perfect \& Gordon RoOKLEdge, RoOKLEDGE's Classic INTERNATIONAL TYPE FindeR: THE ESSENTIAL HANDBOOK OF TYPEFACE RECOGNITION AND 
The University of Kansas School of Law obtained the Miller \& Chase broadside as a single item, and therefore without accompanying material. ${ }^{13}$ It is unknown whether this advertisement was inserted in the Courier or distributed through other means. However, the evidentiary text-“"COURIER' PRINT"- concluding the advertisement, points to the newspaper having provided the production services for the attorneys. It is likely the single remaining instance of multiple copies printed, thus making it the ideal copy. It may also serve as an example of broadside advertising and its physical attributes during the late nineteenth century in the United States and Kansas.

\section{B. Dating the Broadside}

Internal evidence permits us to date the broadside with some accuracy. We know that the law firm of Miller \& Chase was formed and active no later than 1870. Second, and importantly, the broadside was printed by the Wilson County Courier. The Courier was printed at Fredonia between October 1866 and December 1870, when publication was suspended. ${ }^{14}$ It is not at all unusual that local newspapers printed the broadside. During this period in Kansas newspaper owners often also undertook to do job printing as a way of supplementing income. While it is possible that the broadside was printed on the Courier press after the newspaper was suspended, the fact that the broadside states that it was printed by the Courier provides strong evidence that the paper was still being published when the broadside was produced.

Dating the broadside to 1870 also makes sense in the context of what the broadside was intended by Miller \& Chase to accomplish. While it is not explicitly an advertisement for the firm, it is clear that advertising was, in fact, its principle purpose, since it would have brought the law firm to the attention of anyone concerned with probating or administering estates in Kansas. Further, the typographical layout of the broadside with the law firm's name in the largest type at the top of the text also suggests that it was designed, first and foremost, to bring the firm to the attention of the public. Finally, since 1870 was the year in which the firm was established, this would have been the time when

SELECTION (2004)

13. The item was found listed in the online catalog of The Lawbook Exchange, Ltd. (Clark, New Jersey), http://www.lawbookexchange.com, and purchased and returned to Kansas in June 2014.

14. Kansas State Board of Agriculture, First Biennial Report for 1878-1879 (1878), available at www.ksgenweb.com; William E. CONNElley, History OF KANSAS NEWSPAPERS 314 (1916). 
Miller \& Chase would have felt the need to publicize both its existence as a law firm and its areas of practice.

\section{The Content of the Broadside}

The term broadside is generally accepted to refer to a single sheet, printed on one side, for the purpose of advertisement or notification to be publicly distributed. ${ }^{15}$ The broadside is addressed to those people interested in practice in Kansas probate courts by stating it is "instructions to Executors and Administrators" of wills. The instructions for the appointment of executors and administrators then follow with a list of the property that passes to widows under Kansas probate law followed by instructions for drawing up the inventory of an estate. The most prevalent printing on the broadside includes the names of the attorneys, "Miller \& Chase, Attorneys at Law;" where they are located, "Fredonia, Wilson County, Kansas;" their specialty, "Practice in the Probate Court," and who might find their services useful, "Executors and Administrators." From the predominance of this information forefront on the broadside, and from the later mention that the document is for use by clients, one may deduce that, more than instructing those tasked with executing wills, Miller \& Chase is informing family survivors that they may hire out these services to knowledgeable, local attorneys.

\section{Reprinting of the General Statute}

The broadside "compiles from the Statutes" chapter 37, "Executors and Administrators." 16 Most specifically, sections 44 through 52. The first three (I-III) instructions presented are generalizations and simplifications of sections of the statute. Instruction I simplifies language from section 44, and instruction II uses section 39. Instruction III, being the bulk of the printed text, comprising its midsection, is verbatim of section $49,{ }^{17}$ forgiving the printer a single term omission. There are, however, liberties of punctuation and emphasis taken-some pointed out as intentional and others the reason is unknown. Miller \& Chase instructs, "The appraisers value nothing in this list, except any excess there may be under the two classes in italics." Those italic instances within the broadside are presented in normal typesetting in the statute itself. It can be presumed that Miller \& Chase is pointing out

15. The Bookman's Glossary 28 (Jean Peters ed., 1975).

16. Kan. Stat. Ann. $\S \S 37-44$ to -52 (1868).

17. Kan. Stat. Ann. $\S \S 49-440$ to -441 (1868); see also Kan. Stat. Ann. $\S 77-116$ (1923). 
exceptions to help clients avoid any legal pitfalls. Capitalization of nouns and dollar amounts is another of the major emendations found. Again, perhaps it is emphasizing those items of a widow's inventory that may be taken into account as her specified property. Following I-III, instructions IV and V generalize sections, 39, 46, 47, 51, and 52 of chapter 37.

\section{The SignifiCANCE OF THE Miller \& CHASE BROADSIDE}

The fact that the text of the broadside is a reprint of part of the text of the Kansas General Statutes published only two years before raises a central question. Why would such a reprint be of value to anyone so as to justify using the reprint as a form of advertising? In any analysis of this question one must remain cognizant that the reprinting is an expression by Miller \& Chase of the original work contained in the statute intended for specific interpretation by the public, attorneys, and the judiciary. Surely it can be said that the original work, the statute itself, is intended to convey the law and its practice. The broadside parallels the statute deriving potential new outcomes.

Various audiences may have responded differently, and we are only able to use deduction based on evidence available to arrive at an answer. However, it appears the reason why the reprinted text in the broadside was of use to readers is quite simple. Law books were both relatively scarce and quite expensive in 1870s Kansas. Only 5,000 copies of the statutes were to be initially printed and delivered to the Secretary of State for distribution. ${ }^{18}$ Not every lawyer could afford even basic texts and, certainly, few non-lawyers would have owned a law text, particularly the General Statutes of 1868. Additionally, 1868 marked the first codification and publication of the Kansas Statutes, ${ }^{19}$ making distribution of the new laws novel and intriguing. The text that became the standard work on probate law in Kansas, Spalding's Manual of Statutes and Forms, and a Commentary on the Rights, Duties and Powers, of Executors and Administrators of the State of Kansas, was not published until 1881. ${ }^{20}$ The earliest mention of sales lists The Compiled Laws of

\footnotetext{
18. Kan. Stat. Ann. § 119-16 (1868).

19. Robert A. Mead \& Michael H. Hoeflich, Lawyers and Law Books in Nineteenth-Century Kansas, 50 U. KAN. L. REV. 1051, 1063 (2002).

20. Hugh M. Spalding, Manual of Statutes and Forms, and a Commentary on the Rights, Duties AND POWERs, OF EXECUTORs AND AdMinistrators of the State of Kansas (1881).
} 
Kansas, 1881 between $\$ 7.50-\$ 9.00$ and Spalding's at $\$ 3.75 ;{ }^{21}$ both hefty fees at the time also inferring that fourteen years earlier the price would have still been great and perhaps even more scarce.

Both lawyers and the general public would have praised Miller \& Chase for making the text of the requirements for appointing executors and administrators of estates and the proper way to inventory and pass property generally available. Additionally, the authors directly state that the intended audience is clients, thus although the broadside is for public distribution and education, it is equally, if not more so, useful in generating business for the attorneys. Of course, it would have also suggested to its readers involved in estate probate or administration that if they needed expert legal help on the matter, they should contact the law firm of Miller \& Chase.

21. Crane's annual Catalogue of Standard Copyright Blanks, Records and LaW Books, Together with a Daily Calendar of the OfFicial Duties of County, City and TOWNSHIP OFFICERS 71,77 (Geo. W. Crane \& Co., 16th ed. 1884). The only mention of the General Statutes is that they are included within the Compiled Statutes, which also included session laws. It is possible that it was perhaps difficult to obtain just a copy of the statutes. 
I. Have the appraisers duly sworn, who must sign their names to the affidarit. .

II. Administrator or Executor and appraisers inspect the property generally.

III. Set apart the widow's specified property, according to the following list :

SPECIFIED PROPERTY TO WIDOW.-See Gen. Statutes, page $440-1$.

First. The Family Bible, School books and family library.

Second. Family pictures, and musical instruments used by the family.

Third. A seat or pew in any church or place of public worship and a lot in any burial ground.

Fourth. All the wearing apparel of the feceased and his family; all beds, bedsteads and bedding used by the deceased and his family; one cooking stove and appendages, and all other cooking utensils, and all other stores and appendages necessary children; one sewing machine, all spinning wheels and looms, and other implements of industry; and all other household furniture not herein enuof inded, not exceeding in value Five Hundred Dollars.

Fifth. Two Gows, ten Hogs, one yoke of Oxen and one horse or mule, or, in lieu of one yoke of Oxen and one horse or mule, a span or, in lis sheep and the wool from the same, either in the raw material or manufactured into yarn or cloth.

Wixth The necessary food for the support of the stock mentioned in this section, for one year, either provided or growing, or both, this section, for may choose; also one Wagon, cart or dray, two as the widow may choose; also one winsils, including harness plows, one drag, and other farming in value Three Hundred and tackle for teams, not exceeding in value Three Hundred
Dollars.

Sevinth. The grain, meat, vegetables, groceries and other provisions on hand, necessary for the support of the widow and hand, necesthe deceased for one year; sary for their use one year.

(The appraisers value nothing in this

may be under the two classes in italics.

- IV. Then follow on same paper uncer the proper heading, the ventory, including all the goods, chattles, moneys, rights and with the apthe deceased, and not enumerated in the widow's portion, in figures. praised value, in a proper column, set opposite each artgayes, and all

(This enumeration includes notes, bonds, bils, specifying the name of the other securities, debts. and accounts; specifying the name, when due, debtor in each security, date, amount originally payable, and the sum rate of interest, endorsements, if any, with their date, and on eaeh that, in the judgment of the apprarsers, can be collected on 